Article

\title{
Exploring the Impact of Government Regulation on Technological Transitions; a Historical Perspective on Innovation in the Dutch Network-Based Industries
}

\author{
Helen Stout ${ }^{1, *}$ and Martin de Jong ${ }^{1,2,3}$ \\ 1 Erasmus School of Law; Erasmus University Rotterdam, Burgemeester Oudlaan 50, 3062 Rotterdam, \\ The Netherlands; w.m.jong@law.eur.nl \\ 2 Rotterdam School of Management, Erasmus University Rotterdam, Burgemeester Oudlaan 50, \\ 3062 Rotterdam, The Netherlands \\ 3 Institute for Global Public Policy, Fudan University, 220 Handan Road, Shanghai 200433, China \\ * Correspondence: stout@law.eur.nl
}

Received: 11 March 2020; Accepted: 4 April 2020; Published: 11 April 2020

\begin{abstract}
Government interventions can affect processes of technological transition through the enactment of legal and other policy instruments. In this contribution, we concentrated on legal interventions only and examined what they were, the relation between the public and private players that they affected, and the nature of the incentive they provided. We did this for four historical cases in the world of utility industries in the Netherlands in the nineteenth and twentieth centuries. The summarizing results for each case appeared in overview tables which eventually showed whether most of the administered stimuli were negative, neutral, or positive for the action alternatives of the innovating players, and thus the further development of the newly emerging technology. It is hard to escape the conclusion that the common argument and rhetoric that governments normally aim to propel industrial progress by opening a variety of options for innovating private players rings hollow when analyzed more systematically. A higher number of the incentives we found across the four cases were negative rather than positive, while some cases had only negative incentives and none had more positive than negative incentives.
\end{abstract}

Keywords: network-based industries; technological transitions; legal incentives; qualitative game theory; behavioral tactics; innovators

\section{Introduction}

There have been times when products and services that are completely taken for granted today were not present. These products and services include the tap with direct access to clean water and switches on the wall to turn on lights. We may now even do the latter using our smartphone. The importance of such products and services only becomes apparent once delivery stops suddenly. This certainly applies to network-based products and services (gas, water, electricity, public transport, and ICT, etc.) because of their massive societal impact, and imposes a heavy responsibility on governments (Ten Heuvelhof et al. 2009; Kunneke et al. 2009).

Over the years, the way in which authorities around the world have expressed their involvement in these network-based industries has shifted. In the Netherlands, for instance, which the remainder of this contribution will center on, the production and delivery of utilities in the nineteenth century was initially left to the private sector. Later, national and local governments took on many of these tasks, only to relinquish them again towards the end of the twentieth century (Kunneke et al. 2005). In connection with changing self-perceptions over time, the policy instruments that public authorities deployed also altered. For instance, generous concessions were replaced by stricter property rights, 
which in turn were removed in favor of permits without any discretionary power for the administration (Stout and Jong 2005).

In this contribution, we will examine the impact of government regulation on technological transition in these utilities. Since our study covers only historical cases in the Netherlands, and only network-based industries where government involvement is traditionally strong, it can obviously be merely of an exploratory nature, setting the stage for more systematic and comprehensive studies which are hopefully to follow.

Technological transitions can be defined as changes in product and service delivery due to innovation. One example of such a transition is the one from carbon-based gas lights to electricity-based lighting systems. The invention of the dynamo and transformer in the second half of the nineteenth century contributed to electricity evolving into a serious rival for gas-based light in the delivery of public lamps. Dynamos made uninterrupted ignition possible, while transformers enabled low voltage power that was generated at various locations to be transported long distance at a high voltage. For four different cases of such technological transitions in the past two centuries, we will examine how various forms of public regulatory action affected the pace and direction of innovation. Were the institutional incentives provided by rules, regulations, and decisions aimed at breaking down or speeding up the pace of change? Were financial stimuli for innovating agents positive or negative, and/or was their room for maneuver increased or decreased, and why and how? The focus is on especially on transitions, since it is at such time intervals that governments feel compelled to redefine their regulatory role vis-à-vis existing and upcoming technologies (Di Castri and Plaitakis 2018).

The four transitions we selected cover different periods. We have selected the transition from electromagnetic telegraphy to telephony (late nineteenth century), the transition from coal-based gas light to electrical light (around the year 1900), the transition from radiotelephony to radio broadcasting (early twentieth century) and the transition from fixed telephony to mobile telephony (late twentieth century). We cannot claim these cases represent the broader population of technological transitions. They also only reflect the Dutch experience; but jointly they offer us a good first impression of how historically governments in the Netherlands have dealt with innovation. The emphasis in this article is on the formal legal instruments applied by public organizations, i.e., legislation, concessions, permits, authorizations, and contracts.

The central research question is, therefore, what impact does national government action exert on (other) public and private actors which can be seen as the driving forces behind technological transitions? What are the consequences of using formal legal instruments to their positions? Are the numbers of options for these innovators enlarged or reduced or is the impact of government action neutral to the degrees of freedom that these actors have?". With the help of a simple application of concepts derived from qualitative game theory, the stakes of actors and resulting interaction patterns are mapped (Dixit and Nalebuff 1993, 2010; Scharpf 1997; Ten Heuvelhof et al. 2003, 2009). The theory and method underlying our approach are presented in Section 2. The cases will be discussed in chronological order in Sections 3-6. In each of them, the background of the transition is sketched, the actors, goals, and tactics are identified, and subsequently the relevant legal relations are assessed in terms of enhanced or reduced options for actions by innovators. Section 7 closes our contribution with a summary of our findings and implications for future research on this topic. When developing our four case studies, we consulted a number of relevant legal documents as background information not specifically related to any particular findings or part of the text. We have listed them in Appendix A.

\section{Theory and Method}

The question of how legal regulation can be deployed to promote technological innovation and/or mitigate the negative effects of new technologies is highly topical, as can be seen in a growing number of publications on the subject in the academic literature (Van Gestel and Dijck 2011; Butenko and Larouche 2015; Fenwick et al. 2017, 2018). The introduction of statutory experiments and regulatory sandboxes in various countries testifies to this. A number of studies have been published delving 
into the legal, administrative, and other pros and cons of such legal arrangements (Leenes et al. 2017; Philipsen et al. 2020). On the other hand, apart from exploratory studies conducted by De Jong and Stout $(2003,2007)$, little research has been conducted on the role that governments have played in past technological transformations; we took a first step in this direction by analyzing which Dutch legislation was adopted regarding a particular newly emerging technology in the network-based industries, and how this affected the options for action that various involved players were left with.

In line with approaches developed in qualitative game theory (Dixit and Nalebuff 1993, 2010; Scharpf 1997; Ten Heuvelhof et al. 2003, 2009), we assumed that policy actors have certain alternatives to choose from and pick the one that appears to offer the highest benefit to them, but are constrained in their choices by the rules of the game as well as choices made by other actors. However, applied this perspective loosely, in the sense that we: (1) only examined the legal features of the institutional constellation among the players, (2) restricted ourselves to those players involved in technological transformation and affected by the legal changes introduced by the government, and (3) mapped only whether the direction of the legal intervention had a negative, neutral, or positive effect on the options for action that technological innovators had. Given the fact that in our study, we relied on events which occurred in the past and are primarily documented in legal manuscripts and reports, any claim to estimation or quantification of this impact remains unwarranted. Nonetheless, our aim in this contribution was to introduce and initiate a novel approach to examining the channels through which legal government action impinges on the options that societal actors have. We have demonstrated in exploratory fashion for a limited number of cases what these legal channels were, how they affected the action potential of these actors, and what the likely effect on innovation was. At the end, we hope to draw lessons and set the stage for follow-up research that will take this approach further in other countries, for other industries, and hopefully for a higher number of cases.

The method used to establish the effect of legal government interventions during technological transformations is as follows. The government can exert influence on a transition by altering the options for action that the actors that have the potential to speed up innovation have by increasing or decreasing them or leaving them at the same level. An example can clarify this. If the delivery of a particular service is made subject to the granting of a permit by a public authority, the innovator is compelled to apply for permission for something that previously was simply allowed. The freedom to act of the innovator has consequently been reduced. If obtaining this permit takes a long time and it is eventually granted subject to a number of restrictions, freedom of action is further reduced. The impact that the government exerts is defined by comparing the new set of alternatives for action that the innovator has with the set before the intervention. If this set is increased, we speak of a positive incentive; this is the case for instance when the requirement to apply for a permit is abolished. Conversely, when a new rule declares the application of a specific technology a potential threat to public security and subjects it to protracted scrutiny before it can be further developed, we will qualify this is a negative incentive. We refrained from attempting to identify the size of the impact, because insufficient data were available to undertake such an exercise.

In Sections 3-6, four historical cases of a technological transition in the Netherlands are analyzed (electromagnetic telegraphy to telephony, coal-based gas light to electrical light, radiotelephony to radio broadcasting, and fixed telephony to mobile telephony). The fourth and final case happened in a period when the Netherlands was an EU member, as a result of which it was subject to supranational law from Brussels. In this contribution, we limited ourselves to individual actor behavior in specific instances. Since the study centers around the question how legal instruments (from either public or private law) affect relations between actors and behavioral patterns, the legal sources (either national or supranational) were outside our scope. The impact of European legislation on innovation was consequently not a topic of study and it did not appear directly in the fourth case.

In each of the four cases, the following steps were taken. First, we outlined the newly emerging technology, as well as a general overview of the technological transition as it was taking place. Second, we described the legal regime as it existed before the transition, followed by the initial adjustments 
made to this regime and/or the eventual introduction of a new legal regime aimed to fit the new circumstances. At the third stage, the actors involved in the transition were mapped, along with the ideational and material objectives that they had and the behavioral tactics they deployed to realize these objectives. And finally, we identified the legal relation(s) as it/they existed between the relevant public authority and the innovator(s), the legal instrument(s) applied in this relation, and the nature of the incentive(s) provided by the respective incentive(s): positive, neutral, or negative to the innovator(s), and the process leading towards the technological innovation.

\section{Case 1: Transition from Electromagnetic Telegraphy to Telephony}

\subsection{The Telegraph}

The earliest initiatives to introduce the telegraph were left to private ventures. The first electromagnetic telegraph made its appearance in the Netherlands around 1845 and was used for the communication of train service information. Private operators who wanted to offer telegraphy services required a licence from King William I pursuant to a Koninklijk Besluit (royal decree) known as the Telegrafenbesluit 1847 (Telegraph Decree of 1847). But the authorities were not very cooperative, and dragged their feet when it came to dealing with requests for permission to construct and operate telegraph connections. Evidently, the government mistrusted the telegraph; perhaps understandably so. In the middle of the nineteenth century, Europe was on fire as revolutions raged and traditional regimes were being ousted. The government feared that the telegraph could be instrumental in fomenting political agitation. But commercial considerations also played a role: the telegraph could undermine the monopoly position of the state-owned Postal Services, and that was the last thing that the authorities wanted. Wary of this threat, the Telegraph Decree of 1847 stipulated that all telegraph messages had to be registered and that the Postal Services were to receive full compensation for any loss of revenue suffered at the hands of this upstart technology.

Very soon, the disadvantages of entrusting the telegraph to private operators became clear. These entrepreneurs cherry-picked the most lucrative lines, leaving less profitable routes uncultivated. Discontent about this situation led to calls for a nationwide network. These were answered with the introduction of the Telegraafwet on 7 March 1852 (Telegraph Act of 1852), which firmly placed the responsibility for the construction and maintenance of telegraph connections in the state's hands. This resulted in the creation of the Rijkstelegraaf (National Telegraph Service), which initially came under the Ministry of the Interior before being transferred in 1877 to the Ministry of Water Management, Trade and Industry. To complete this process of nationalization, private telegraphy companies were gradually taken over and brought within public control.

\subsection{The Telephone}

The Nederlandsche Bell Telephoon Maatschappij (NBTM) started in 1881 to offer a commercial service using a special telephone connection running from the company's own exchange to a telephone room in the building of the Rijkstelegraaf in Amsterdam. This connection made it possible to pass on telegrams from subscribers to the Rijkstelegraaf, as well as to deliver telegrams received from the Rijkstelegraaf to the addressees. The Rijkstelegraaf also used the telephone in this limited way both to accelerate the transmission of telegrams and to cut the costs of its services: a telephone was a fraction of the cost of a telegraph and much easier to use, so there was no need for expensive trained telegraphists.

Should the telephone have the same legal status as the telegraph?

Right from the outset, the telephone's legal status was a bone of contention. Was the telephone a kind of electromagnetic telegraph, and therefore subject to the Telegraph Act of 1852, or not? The government ingeniously took the view that the telephone should be treated as a voice telegraph. As such, it fell under the normal regime for telegraphy, which meant that a king's licence was needed to use it. But this was not the end of the debate, and it ultimately fell to the court to resolve the issue after a landmark dispute had arisen in 1884 . 
The immediate cause of the court action was that the Nederlandsche Bell Telephoon Maatschappij (NBTM) had strung telephone lines above a building on the Keizersgracht in Amsterdam without requesting the owner's permission. The owner demanded the removal of the telephone lines. In its defence, the NBTM invoked the licence that it had received from the king under the Telegraph Act of 1852. The NBTM argued that the owner was obliged to tolerate the telephone lines, while retaining the right to demand compensation. The court ruled that the NBTM was unable to invoke the Telegraph Act of 1852 which formed the legal basis for its concession. It followed that the NBTM had acted unlawfully by stringing the telephone wires over the building without the owner's permission.

Dissatisfied with this situation, private telephone companies pressed for a new Telephone Act, but little concrete action was taken. The new Telephone Act long remained up in the air and concession holders, fearing that the government might claim monopoly rights (as with the telegraph), were reluctant to make further investments in new local telephone networks. The king, for his part, left new applications for licences unattended. So the stalemate was complete. The uncertainty as to whether the telephone fell within the scope of the Telegraph Act of 1852 also raised another intriguing question: "where did the authority to grant concessions for local telephony lie?". As the construction of a telephone network inevitably involved the use of municipal land, municipal boards argued that this authority rested with them.

The reluctance to invest was also due to the fact that the concessions were rapidly nearing their expiry date. The lack of technical innovation that resulted from this underinvestment led to a steady deterioration of the telephone service. Technical failures, incorrect connections, and delays were the order of the day in the 1890s. The concession holders also charged relatively high rates, partly to compensate for the short useful life of the assets. Clearly, the concession system was not effective and was off-putting for potential subscribers to the service. Municipal boards around the country therefore concluded that the high rates combined with obsolete equipment and underinvestment in the networks was no longer acceptable. Against this backdrop, cities such as Amsterdam, Rotterdam, and the Hague decided not to renew the concession to the NBTM, and set up their own municipal telephone services instead.

\subsection{A Brand New Legal Regime}

Early in the twentieth century, the telephone was finally enshrined in law as a technology in its own right. On 11 January 1904 the Telegraaf- en Telefoonwet (Telegraph and Telephone Act of 1904) was enacted; it came into force on 1 March 1904 (Collette 1904). The law explicitly recognized both the telegraph and the telephone as separate entities, and allocated the primary responsibility for the construction and operation of telegraph and telephone networks to the government. Private initiatives to construct and/or operate telephone networks were only permitted in exceptional cases subject to a concession from the king. The reason for requiring royal permission was to emphasize that the construction and operation of these services was a matter of public interest. According to the government, a concession underlined more so than a licence that the service fell within the responsibilities of government (Ten Brink et al. 1954, p. 306). The Telegraph and Telephone Act of 1904 marked the end of the municipal telephone concessions.

\subsection{Identification of Actors, Objectives and Tactics}

The actors involved, their objectives and tactics from the case are shown in Tables 1 and 2 below. This does not concern actors in the legal sense (natural or legal persons), but actors in the game theory sense, i.e., operationalized as an acting entity. The objectives are derived and can be either of an ideal or a material nature. Ideal objectives can be derived directly from the texts of official government documents. These objectives are explicitly traceable in the empirical material. Material objectives are more difficult to determine. These are the objectives that are attributed to actors. They are based on empirical evidence, but only indirectly. Actors can have both ideal and material objectives. For instance, a public actor who waits a long time before awarding a concession for reasons 
of self-interest is perceived in the analysis to have both an ideal objective (the purpose for which the concession is required) as well as a material objective (e.g., delay the market entry of a competitor). Actors developed tactics to achieve their objectives. These can be covert, and not openly admitted, such as procrastination and obstruction. There need not be a one-on-one relationship between objectives and tactics. The identified tactics can relate to multiple objectives, while a specific objective can also be achieved through multiple strategies.

Table 1. Private actors.

\begin{tabular}{ccc}
\hline Private Actors & Objective(s) & Tactics \\
\hline Telegraphy operators & generate profit from telegraphy & apply for licence \\
Telephony operators & generate profit from telephony & apply for concession \\
Homeowners & protect property & start court action \\
Telephone customers & high-quality and affordable & take out contract with provider or not \\
& telephone service & \\
\hline
\end{tabular}

Table 2. Public actors.

\begin{tabular}{|c|c|c|}
\hline Public Actors & Objective(s) & Tactics \\
\hline \multirow{3}{*}{ King William I } & $\begin{array}{l}\text { maintain power versus } \\
\text { legislator/parliament }\end{array}$ & $\begin{array}{l}\text { adopt laws by royal decree (Telegraph } \\
\text { Decree of 1847) }\end{array}$ \\
\hline & control communications & $\begin{array}{l}\text { licence subject to mandatory registration of } \\
\text { transmitted messages }\end{array}$ \\
\hline & protect state Postal Services & licence subject to compensation \\
\hline \multirow[b]{2}{*}{ Minister of the Interior } & nationwide coverage & $\begin{array}{l}\text { construction and maintenance of telegraph } \\
\text { network at state's expense }\end{array}$ \\
\hline & $\begin{array}{l}\text { secure profitable operation of } \\
\text { telegraphy }\end{array}$ & $\begin{array}{l}\text { establish statutory monopoly of } \\
\text { Rijkstelegraaf based on Telegraph Act of } \\
1852 \\
\text { the acquisition of existing companies by the } \\
\text { State }\end{array}$ \\
\hline \multirow[b]{2}{*}{$\begin{array}{l}\text { Minister of Water } \\
\text { Management, } \\
\text { Trade and Industry }\end{array}$} & $\begin{array}{l}\text { obtain legal control over } \\
\text { telephone/incorporate into } \\
\text { existing legal framework }\end{array}$ & rename telephone as voice telegraph \\
\hline & $\begin{array}{l}\text { protect interests of Rijkstelegraaf } \\
\text { against competition from } \\
\text { telephone }\end{array}$ & $\begin{array}{l}\text { delay decision-making on } \\
\text { telephony/postpone handling of } \\
\text { applications for concessions } \\
\text { concession for telephony subject to } \\
\text { guarantee that operator compensates lost } \\
\text { telegraphy revenue on same route }\end{array}$ \\
\hline Court & $\begin{array}{l}\text { prove independence versus other } \\
\text { powers }\end{array}$ & $\begin{array}{l}\text { impede application of Telegraph Act of } 1852 \\
\text { to telephony }\end{array}$ \\
\hline \multirow{5}{*}{ Municipalities } & connections for everyone & concession subject to obligation to connect \\
\hline & $\begin{array}{l}\text { good-quality affordable telephony } \\
\text { for residents }\end{array}$ & concession subject to maximum rate \\
\hline & control over telephony & limited concession period \\
\hline & $\begin{array}{l}\text { cautious approach/keep all options } \\
\text { open for the future }\end{array}$ & $\begin{array}{l}\text { concession on condition that ownership } \\
\text { reverts to municipality when concession } \\
\text { expires }\end{array}$ \\
\hline & $\begin{array}{l}\text { protect municipal autonomy } \\
\text { versus National Government }\end{array}$ & $\begin{array}{l}\text { require operators to obtain concession from } \\
\text { municipality despite king having the } \\
\text { primary authority based on Telegraph Act } \\
\text { of } 1852 \text {. }\end{array}$ \\
\hline
\end{tabular}




\subsection{Relevant Legal Relationships}

Table 3 shows the three relevant relationships from the case, as well as the formal legal instruments governing these relationships. The nature of the incentive is indicated in the last column. The licensing requirement as laid down in the Telegraph Act of 1852 created a barrier both for telegraphy and telephony operators. This impeded the development of their business operations. In requiring a concession from the king, the new Telegraph and Telephone Act of 1904 maintained a barrier to market entry but also gave operators of local telephone services more room to operate. Unlike the operators of long-distance telephone services, the local companies did not constitute a threat to the Rijkstelegraaf, and were allowed to operate without too much meddling from the Minister of Water Management, Trade and Industry. For this reason, the nature of the incentive in the final column can be classified as slightly or moderately positive.

Table 3. Relevant legal relationships.

\begin{tabular}{lll}
\hline \multicolumn{1}{c}{ Relationship } & \multicolumn{1}{c}{ Legal Instrument } & Nature of Incentive \\
\hline $\begin{array}{l}\text { Telegraphy operators versus Minister of the } \\
\begin{array}{l}\text { Interior (1852-1869)/Minister of Finance } \\
(1870-1877) / \text { Minister of Water Management, } \\
\text { Trade and Industry (1877-1905) * }\end{array}\end{array}$ & $\begin{array}{l}\text { licence from the king based on } \\
\text { Telegraph Act of 1852 }\end{array}$ & negative \\
\hline $\begin{array}{l}\text { Telephony operators versus Minister of } \\
\text { Water Management, Trade and Industry }\end{array}$ & $\begin{array}{l}\text { licence from the king based on } \\
\text { Telegraph Act of 1852 }\end{array}$ & negative \\
\hline $\begin{array}{l}\text { Local telephony operators versus } \\
\text { municipalities }\end{array}$ & $\begin{array}{l}\text { abolition of concession from } \\
\text { municipal council in Telegraph } \\
\text { and Telephone Act of 1904 }\end{array}$ & positive \\
\hline
\end{tabular}

* Telegraphy (and, by extension, telephony) has over the years come under different ministries.

\section{Case 2: The Transition from Coal Gas Light to Electrical Light}

\subsection{Coal Gas Light}

The first initiatives to introduce coal gas light in the Netherlands were taken by private entrepreneurs. Great Britain was the pioneer in the field. With its numerous coal mines and advanced machine industry, the country was the undisputed technology leader and brimmed with commercial ambition. King William I acknowledged the benefits of gas light for the industrial development of the Netherlands but did not like the idea of the British controlling the gas industry.

Entrepreneurs seeking to set up a gasworks required permission from the king pursuant to the Trafiekenbesluit 1824 (Royal Decree on licences for the incorporation of certain types of manufacturing and processing factories of 31 January 1824). The king stretched the scope of his powers in this area as far as he could. In his view, he should also have the power to decide on applications for permission to break open municipal roads and lay pipelines and cables in municipal land. As a true champion of the national cause, he did not hesitate to give national industrialists preferential treatment over foreign investors by obliging licence holders to procure goods and materials from Dutch companies. Municipal authorities, for their part, took little notice of the king's aspirations to be the central player and determined that gas plants also required municipal approval. Usually this approval, called a "concession", was only granted on payment of a "retribution". Retributions that exceed compensation for the actual costs are classified as illegal in the literature on the grounds that such payments are essentially a consumption tax rather than a reimbursement of costs, and therefore require a legal basis (Lamers 1887, pp. 192-93). Sometimes municipal authorities even negotiated a share in the profit. Municipalities justified their authority to make a concession mandatory for the use of municipal land on the fact that they owned the land. See, for instance, the agreement concluded on 3 May 1844 between the municipal board of the Hague and Van Oven and Goldsmid, which determined that the other party was licensed until 1874, to the exclusion of all others, to lay gas pipes under streets and 
roads (Mac Lean 1977, p. 4). However, this municipal practice was only put on a legal footing after the introduction of the Gemeentewet 1851 (Municipality Act of 1851). In 1875 the Hinderwet (Nuisance Act of 1875) ended the king's powers in this area once and for all. From now on, the municipal board was the body authorized to grant licences for the construction of a new gasworks. Where necessary, these licences also contained specific conditions to prevent danger, damage, or nuisance.

\subsection{Street Lighting}

Street lighting played a central role in the development of the Dutch gas industry during the nineteenth century. Utrecht is a case in point. As soon as gas manufacturer W. H. de Heus started providing public lighting to this city in 1842, pipe gas became available to private individuals (Van Hulzen 1976, pp. 63-73). The contracts that municipalities awarded for the supply of gas for public street lighting were not just prestigious projects for the gas companies, but also generated sufficient funds for them to continue expanding the gas pipe system. Buildings and homes could be connected at little extra cost, leading to a steadily widening network. Street lighting and lighting in public buildings was a large cost item for municipalities. Many therefore used their position as the grantor of concessions to drive a hard bargain for the best deal. The gas companies, in turn, sought to compensate the resulting reduction in revenue by charging higher rates to private individuals (Van den Noort 1993, pp. 28-30,33). This was perfectly legal. In fact, some concession contracts even included a specific clause allowing the gas company to compensate the lower revenues from street lighting by charging consumers higher prices (Van den Noort 1993, p. 34).

In the second half of the nineteenth century, the negotiations between private operators and municipalities about the price and quality of the gas supply became increasingly difficult and fractious. High prices and stagnations in supply caused growing discontent among customers. Eventually, these factors prompted the municipalities to take over the private gasworks (Zadoks 1899, pp. 9, 17). Sometimes municipal authorities even decided to set up their own gasworks, in which case they did not hesitate to snuff out private competition by cancelling concessions early or refusing to renew them on expiry (Zadoks 1899, p. 10): "The cancellation of the concessions makes the continuation of both of the existing gasworks as such impossible". But cancellation was not always a straightforward process. Witness the hard-fought termination of the Hollandse Gasfabriek concession by the municipality of Amsterdam effective from 1 November 1885 (Zadoks 1899, pp. 33-38). Concessions usually included a public acquisition clause ("naasting"), whereby the ownership of the gasworks passed, upon payment, to the municipality after the concession expired. This was common practice, even though the public authorities often had to pay high prices. These large sums did not put them off because they were well aware of the large profits that were to be made from gasworks.

\subsection{Electric Light}

Towards the end of the nineteenth century, the first electrical engineering companies came into existence in the Netherlands. Their role was to supply industry with electric light. Generation took place at a decentralized level with the aid of stand-alone generators. Electricity had many advantages over gas: it was cleaner, used no oxygen, and posed no risk of fire or explosion. But it was still too expensive for households, so the municipal gasworks could continue to expand unimpeded, particularly as falling prices opened up a steadily widening market.

Encouraged by positive experiences abroad, a few pioneering spirits put forward plans for the construction of a power plant. But their chances of success were bleak. The price tag was high: double the cost of a gasworks. Municipalities were also not cooperative, and their stalling tactics were often sufficient to put the applicants off. Moreover, those that persisted were confronted with unfavourable terms, such as restrictions on the market that they were allowed to serve. Some municipalities also demanded a share in the profits. Others merely offered "trial concessions", which were surrounded by uncertainty and only remained valid until cancelled. All these measures made the construction of new power plants a highly precarious venture of unpredictable profitability (der Techniek 1993, pp. 148-54). 


\subsection{Traction and Power Supply}

Some municipalities, however, recognized that power and traction were the key to modernization and stimulated initiatives to build electricity plants. Rotterdam needed to power its port, while Amsterdam and Utrecht wanted to build electric tram systems. By 1918, the Netherlands had 82 electricity plants, of which 24 were in municipal hands. These plants covered $74 \%$ of the total installed electricity capacity. Gradually, the production of gas from coal ground to a halt and the old gasworks started to be decommissioned.

\subsection{Alternating Current}

The introduction of direct current gave the electricity sector a strong impulse. Direct current (to replace alternating current) allowed the transmission of electricity over longer distances. As a result, urban plants could deliver power to areas far outside the municipal boundaries. The electrification of the countryside was suddenly within reach, but there was a threat that the electricity system would become fragmented. Initially, provincial authorities sought to improve the coordination of supply by imposing regulations whereby the generation of power was subject to prior provincial permission. However, this regulatory instrument soon proved ineffective, and the authorities decided to set up their own provincial power plants. Accordingly, almost all provinces proceeded to build their own power plants between 1910 and 1920, thereby realizing virtually nationwide coverage.

\subsection{Identification of Actors, Objectives and Tactics}

The actors involved, their objectives and tactics are shown in Tables 4 and 5 below.

Table 4. Private actors.

\begin{tabular}{ccc}
\hline Private Actors & Objective(s) & Tactics \\
\hline Coal gas light operators & generate profit from coal gas light & apply for concession \\
\hline Electricity operators & generate profit from electricity & apply for concession \\
\hline Gas light customers & $\begin{array}{c}\text { secure good-quality and affordable } \\
\text { connection to network }\end{array}$ & take out contract with provider or not \\
\hline
\end{tabular}

Table 5. Public actors.

\begin{tabular}{cll}
\hline Public Actors & \multicolumn{1}{c}{ Objective(s) } & \multicolumn{1}{c}{ Tactics } \\
\hline \multirow{3}{*}{ King William I } & $\begin{array}{l}\text { consolidate own power versus } \\
\text { legislator/parliament }\end{array}$ & $\begin{array}{l}\text { adopt laws by Royal Decree (Decree on the } \\
\text { incorporation of manufacturing and } \\
\text { processing factories of 1824) }\end{array}$ \\
\cline { 2 - 3 } & $\begin{array}{l}\text { protect national industry against foreign } \\
\text { competition }\end{array}$ & $\begin{array}{l}\text { licence conditional on procurement of } \\
\text { goods and materials from Dutch companies }\end{array}$ \\
\hline \multirow{3}{*}{ Municipalities } & good-quality affordable gas light for itself & $\begin{array}{l}\text { concession conditional on affordable rates } \\
\text { for itself and less affordable rates for } \\
\text { residents }\end{array}$ \\
\cline { 2 - 3 } & $\begin{array}{l}\text { good-quality affordable gas light for } \\
\text { residents }\end{array}$ & \begin{tabular}{l} 
concession conditional on maximum rate \\
\cline { 2 - 3 }
\end{tabular} \\
\cline { 2 - 3 } & secure profitability of municipal gasworks & $\begin{array}{l}\text { delay decision-making and/or postpone } \\
\text { handling of applications for electricity } \\
\text { concessions } \\
\text { concession conditional on profit-sharing } \\
\text { with municipalities }\end{array}$ \\
\hline
\end{tabular}


Table 6 shows the two relevant relationships from the case, as well as the formal legal instruments governing these relationships. The last column indicates the nature of the incentive.

Table 6. Relevant legal relationships.

\begin{tabular}{ccc}
\hline Relationship & Legal Instrument & Nature of Incentive \\
\hline Gas operators versus municipalities & concession from municipal board & negative \\
\hline Electricity operators versus municipalities & concession from municipal board & negative \\
\hline
\end{tabular}

By making concessions mandatory, the municipal board created a barrier for both gas and electricity operators. This impeded the development of their business operations. Electricity operators also often had to fight an uphill battle against the municipal gasworks, with many municipalities making concessions subject to particularly tough conditions.

\section{Case 3: The Transition from Radiotelephony to Radio Broadcasting}

\subsection{Radiotelegraphy}

During the mid-nineteenth century, enquiring minds started to explore the possibility of wireless telegraphy, i.e., the transmission of a telegraphic message through the air rather than through a metallic conductor. It was not until the end of that century that the Italian physicist and inventor Marconi produced the answer to this question with a series of successful test transmissions using a spark radio transmitter. His experiments with antennae unlocked the knowledge that led to wireless telegraphy based on electromagnetic waves. In 1897 he set up the Wireless Telegraph and Signal Company Ltd., thus laying the foundations for the commercial operation of wireless telegraphy. This new technology was mainly applied in the maritime sector for sending messages between coastal stations and ships out at sea. The Rijkstelegraaf (National Telegraph Service) kept a close eye on the developments, all the more so when the Marconi Wireless Telegraph Company set its sights on the Netherlands. Radiotelegraphy and telephony, like their cable-bound counterparts, came under the Telegraph and Telephone Act of 1904. Telegraphy and telephony operators required a licence from the Minister of Water Management in order to provide their services. As the signals were broadcast through the air in all directions, third parties could easily read the messages or listen in on the sender and recipient. This gave rise to a legal problem. How could the confidentiality of telegrams be safeguarded in a situation where the sender-recipient relationship had been replaced with a relationship involving a sender and multiple recipients whose identity, moreover, was not known?

Around 1908 the first radio amateurs came to the fore. These people were hobbyists who built their own transmitters and crystal sets and enjoyed secretly listening in on messages sent by others. Initially, all that could be heard was the non-descript whistling and buzzing of Morse Code signals, but this changed when the invention of the vacuum tube also enabled the transmission of voice and music. As with radio telegraphy, the transmission of radio signals through the air made use of carrier waves. Besides picking up the messages of commercial stations that were often transmitted in code, the radio amateurs mainly listened to each other.

Radio telegraphy required a licence. The private possession and use of receivers was forbidden, but this did not put off the radio amateurs. Strictly speaking, the Telegraph and Telephone Act of 1904 contained no explicit arrangements for receivers. The ban was laid down in a different document: an algemene maatregel van bestuur (order in council) (Collette 1904, opp. 87-93). There were two reasons for prohibiting the private use of receivers, popularly known as the "listening ban". One was the fear that inexpert use of radio sets would interfere with official radio communications; the other was the fear that military communications would be intercepted, thus compromizing national security. 
The "listening ban" turned out to be a paper tiger. Receivers were simple to build and enforcement was virtually impossible. The ban only deterred a few law-abiding souls from indulging in their favourite pastime. In fact, for many of the hobbyists, the clandestine nature of their activity added to the excitement of trawling the airwaves for signals and messages (De Boer 1946, p. 13; Rollema 1995, p. 24). The difficulty of enforcement was one reason why the "listening ban" was lifted in 1914. Lely, the Minister of Water Management, defended the move by arguing that a receiver, being an "innocent" device and only suitable for picking up signals, could not be regarded as a radio telegraph or telephone in the meaning of the law. However, the listening ban was briefly reinstated when the First World War broke out. This partly prompted the foundation of the NVVR, Nederlandsche Vereniging voor Radiotelegrafie (Netherlands Association for Radiotelegraphy), in 1916. The object of this organization was to represent the wider interests of radio hobbyists, but its first concern was to press for the abolition of the listening ban. Thanks to the influence of some prominent members of the NVVR, the minister repealed the listening ban in 1917, before the war ended. That said, the private ownership and use of transmission equipment was forbidden from the outset. Radio hobbyists had to wait until 1930 before the first personal broadcasting licences were issued.

\subsection{Radiotelephony}

That wireless signals could be picked up by outsiders was long perceived as a drawback of radiotelegraphy. But then the idea took root that the "broadcasting" of messages across a wide area also opened up exciting new opportunities. It meant that a large audience could be reached from a single point. The first radiotelephony broadcaster in the Netherlands was the Nederlandse Radio Industrie (NRI; Netherlands Radio Industry), a company that manufactured components for wireless transmission and reception equipment. The broadcasts, which were aimed at radio amateurs, were carried out to test and promote the factory's products. By broadcasting spoken and music programs for a wider audience at fixed times, the NRI unwittingly became the first broadcasting station in the world (Schaafsma 1970, p. 7). Other factory broadcasters followed in the NRI's footsteps but disappeared as quickly as they came. Broadcasting turned out to be extremely costly and a lack of funding was usually the main reason for their speedy withdrawal. Parties with broadcasting ambitions, incidentally, were required to possess an experimental broadcasting licence.

Radio technology developed rapidly. As radio sets became increasingly sophisticated and easier to operate, a new group of enthusiasts emerged. Unlike the technology-loving radio amateurs, they were mainly interested in the radio as a medium for listening to programs. Demand for radio receivers went through the roof.

\subsection{Radio Broadcasting}

The factory broadcaster of Nederlandse Seintoestellen Fabriek (NSF), a specialist in shipping communication, started broadcasting programs in 1923. Its intentions, too, were purely commercial: to open a new market for the sale of radio parts as well as complete radio sets. In 1924, the factory set up a committee named Hilversumse Draadloze Omroep (HDO), which was dedicated to the production and broadcasting of radio programs. The factory provided the transmitter and the technical staff. The HDO's object was not to make a profit, but to ensure the appropriate expenditure of the money donated by its listeners. In the first years of its existence, the number of voluntary donors grew exponentially. The contributions from listeners were used to broadcast a varied program several evenings of the week. In order to satisfy as many listeners as possible, the HDO presented itself as a music broadcaster for a wide audience. The HDO concluded an exclusive contract with the NSF in order to secure sufficient broadcasting time. 
The big breakthrough for the NSF came when the factory started to rent out air time to broadcasting organizations, which rapidly evolved into mouthpieces of segregated groups in society that adhered to a common religious, political, or social creed (the so called "zuilen"). The airtime that the NSF rented out to broadcasting organizations increasingly encroached upon the broadcasting time that was available to the HDO. As the number of broadcasting organizations grew and demand for transmission capacity increased, a new problem arose, namely the need to manage the broadcasting network. The various broadcasting organizations considered setting up their own stations, but the Minister of Water Management feared that such a free-for-all approach would lead to a fragmented and commercially unviable broadcasting landscape. In 1935 the introduction of the Radio-Omroep-Zenderwet (Radio Broadcasting Station Act of 1935) led to the foundation of a public-private company, NV Nederlandse Omroep Zender Maatschappij (NOZEMA), which was given a monopoly over the management of the broadcasting network. The participants in NOZEMA were the government and the four largest broadcasting organizations. The birth of NOZEMA marked the end of private factory broadcasters. Pursuant to the Telegraph and Telephone Act of 1904, an order in council was adopted for the regulation of the radio broadcasting system, including the allocation of broadcasting time to the various broadcasting organizations. Though not a law in the formal sense of the word, this became known as the Radiowet 1928 (Radio Act of 1928).

\subsection{Identification of Actors, Objectives and Tactics}

The actors involved, their objectives and tactics from the case are shown below in Tables 7 and 8 .

Table 7. Private actors.

\begin{tabular}{|c|c|c|}
\hline Private Actors & Objective(s) & Tactics \\
\hline Radiotelegraphy operators & $\begin{array}{l}\text { generate profit from } \\
\text { radiotelegraphy }\end{array}$ & $\begin{array}{l}\text { apply for licence pursuant to Telegraph } \\
\text { and Telephone Act of } 1904 \\
\text { look for niches in the Rijkstelegraaf } \\
\text { (National Telegraph) services, which } \\
\text { held the statutory monopoly }\end{array}$ \\
\hline Radio amateurs & $\begin{array}{l}\text { mutual communication via } \\
\text { airwaves } \\
\text { sharing of technical knowledge } \\
\text { enjoyment of new invention }\end{array}$ & $\begin{array}{l}\text { incorporation of NVVR (Netherlands } \\
\text { Association for Radiotelegraphy) }\end{array}$ \\
\hline $\begin{array}{l}\text { Nederlandse Seintoestellen } \\
\text { Fabriek }\end{array}$ & $\begin{array}{l}\text { generate profit from } \\
\text { production/sale of (parts of) radio } \\
\text { sets }\end{array}$ & $\begin{array}{l}\text { apply for experimental broadcasting } \\
\text { licence and create factory broadcasting } \\
\text { station } \\
\text { transmit commercials via the airwaves } \\
\text { rent out broadcasting time to } \\
\text { broadcasting organizations }\end{array}$ \\
\hline \multirow[t]{2}{*}{$\begin{array}{l}\text { Hilversumse Draadloze } \\
\text { Omroep }\end{array}$} & $\begin{array}{l}\text { produce and broadcast radio } \\
\text { programs for listeners }\end{array}$ & broad programming \\
\hline & $\begin{array}{l}\text { protect position in the airwaves } \\
\text { against competitors }\end{array}$ & conclude contract with NSF \\
\hline \multirow[t]{2}{*}{ Broadcasting organizations } & $\begin{array}{l}\text { broadcast "segregated" } \\
\text { (political/social/religious) } \\
\text { messages/programmatic } \\
\text { autonomy }\end{array}$ & $\begin{array}{l}\text { rent airtime from factory broadcaster } \\
\text { NSF }\end{array}$ \\
\hline & $\begin{array}{l}\text { increase membership } \\
\text { increase airtime }\end{array}$ & participate in NV NOZEMA \\
\hline Listeners & $\begin{array}{l}\text { good-quality and affordable radio } \\
\text { broadcasting service }\end{array}$ & $\begin{array}{l}\text { voluntary contribution } \\
\text { membership of broadcasting } \\
\text { organization }\end{array}$ \\
\hline
\end{tabular}


Table 8. Public actors.

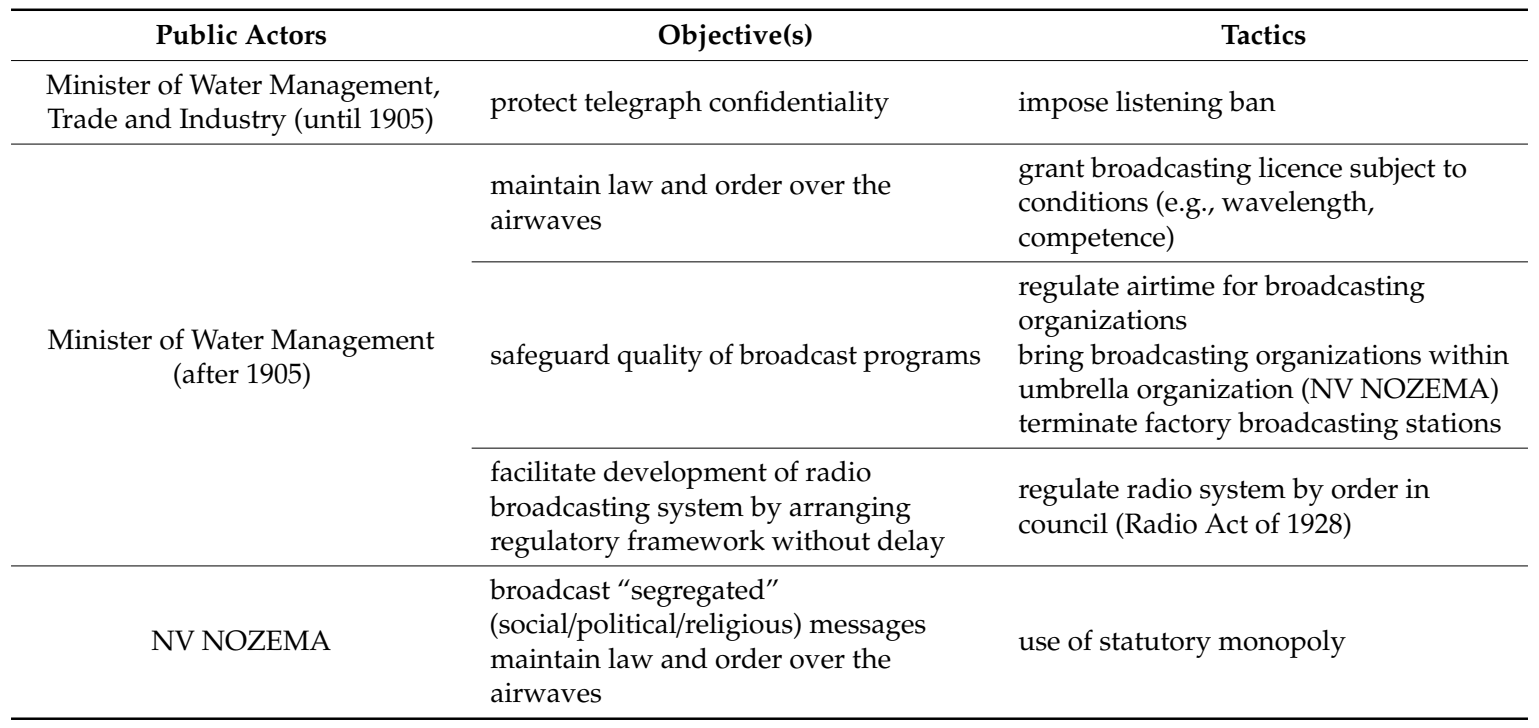

Table 9 indicates the four relevant relationships from the case as well as the formal legal instruments governing these relationships. The nature of the incentive is indicated in the last column.

Table 9. Relevant legal relationships.

\begin{tabular}{ccc}
\hline Relationship & Legal Instrument & Nature of Incentive \\
\hline $\begin{array}{c}\text { Radio amateurs versus Minister of Water } \\
\text { Management }\end{array}$ & listening ban & negative \\
\hline $\begin{array}{c}\text { NRI and other radio manufacturers } \\
\text { versus Minister of Water Management }\end{array}$ & experimental broadcasting licence & positive \\
\hline $\begin{array}{c}\text { Broadcasting organizations versus } \\
\text { Minister of Water Management }\end{array}$ & broadcasting licence & negative \\
\hline NSF versus legislator & $\begin{array}{c}\text { creation of Radio Broadcasting } \\
\text { Station Act of 1935 with } \\
\text { incorporation of NV NOZEMA }\end{array}$ & undetermined \\
\hline
\end{tabular}

The government initially put a brake on the development of radiotelegraphy and telephony. Restrictions were imposed in the form of a listening and broadcasting ban. Nor was this restrictive stance significantly altered by the revocation of the listening ban, because radio amateurs continued to be deprived of the right to broadcast, which was what they wanted to do most. There were no legal remedies (such as a licensing system) for individuals to get around this ban. The Minister of Water Management's permission to set up and use factory broadcasting stations did provide a positive incentive for the further development of the technology. These stations were largely left alone to experiment with radio broadcasts without too much official meddling. Ultimately, however, the government's commitment to protecting a segregated radio system organized along social, political, and religious lines produced negative incentives. The market was closed to new entrants, and therefore no longer provided fertile ground for technical innovation. The incorporation of the Radio Broadcasting Station Act of 1935 marked the replacement of an open system with a closed system. There was no room for new broadcasters, which was potentially positive for the existing broadcasting stations in the short term, but not in the longer term. The positives and negatives do not cancel each other out, which is why the nature of the incentive is undetermined. 


\section{Case 4: The Transition from Fixed to Mobile Telephony}

\subsection{Fixed Telephony}

As described in Section 3, telephony was initially in the hands of private operators, but in certain cities these were displaced in due course by municipal boards who started offering telephone services themselves. The situation regarding long-distance telephony was somewhat different. From the outset, only a single provider was active in this area: the Nederlandsche Bell Telephoon Maatschappij (NBTM). But as it slowly became clear that telephony was crucial to the country's economic development, the NBTM was compelled to sell its long-distance network to the government in 1897. From then onwards, long-distance telephony became the responsibility of the Administratie der Posterijen en Telegrafie (APT), a department of the Ministry of Water Management, Trade and Industry. As time progressed, the ATP started to buy up local networks. In this way, private and municipal telephone networks passed step by step into state ownership. In many cases, the acquired company continued to run the operations on the state's behalf for several more years. In 1915, the ATP was transformed into the Staatsbedrijf der Posterijen en Telegrafie, with "telephony" still conspicuously absent in the name. The addition of "telephony" did not happen until 1928, when the company was renamed the Staatsbedrijf der Posterijen, Telegrafie en Telefonie (PTT). In the three major cities-Amsterdam, Rotterdam, and the Hague - the municipal telephony services continued to exist until the arrival of the German occupation forces in 1940. During the war, these three remaining municipal telephony services were also placed within the state-owned Staatsbedrijf der PTT through public acquisition ("naasting"). The privatization of the PTT as initiated under the Nazi occupation was reversed after the war. In the post-war era, the state-owned Staatsbedrijf der PTT-which came under the auspices of the Ministry of Traffic and Water Management-continued to hold a monopoly on home telephone installations in the Netherlands, which lasted until the end of the twentieth century.

\subsection{Exclusive Concession for KPN}

In 1988, the Telegraph and Telephone Act of 1904 was replaced by the Wtv, the Wet op de Telecommunicatievoorziening (Telecommunication Services Act), paving the way for the privatization of the state-owned Staatsbedrijf der PTT. The public limited company Koninklijke PTT Nederland (KPN) came into existence on 1 January 1989, with the state remaining its sole shareholder until the initial public offering in 1994. Thereafter, the government steadily reduced its stake in the company, culminating in its full withdrawal in 2005.

The incorporation of KPN in 1989 did not yet end the former state company's monopoly. KPN received an exclusive concession for the construction, operation, and maintenance of the telecommunication infrastructure. This exclusive concession was conditional on the provision of certain "assigned services", including fixed telephony as well as public telephone boxes. Fixed telephony was perceived to be such an important public service that its availability to everyone on equal terms and at an affordable price had to be guaranteed. In accordance with the then applicable Services Directive of 1990, which excluded telephony from liberalization, KPN also long held an exclusive concession for mobile telephony (initially predominantly used in cars).

At the end of the twentieth century, the European Union embarked on a course towards the full liberalization of telecommunication services. One step in this direction involved limiting KPN's concession to the fixed telecommunications infrastructure and fixed over-the-air connections, effective from 1 September 1994. From then onwards, the telephony services with and between mobile users on land and inland waters no longer belonged to the services that were exclusively assigned to KPN as concession holder. To achieve the envisaged competition in the mobile telephony market, other players had to be given access to the over-the-air infrastructure.

One crucial step was to develop a new frequency allocation system. The initial intention in the Netherlands was to merely amend the Wtv, but it was soon found that a more radical legislative overhaul was required. The existing legal framework, which was based on a single monopolist with an exclusive 
concession, was irreconcilable with the ambition to create an entirely open telecommunications market. Accordingly, the Wtv was replaced with the new Tw, the Telecommunicatiewet (Telecommunications Act), of 19 October 1998. Based on Article 9.2 of the Tw, the public pay phone system (public telephone boxes) remained the responsibility of KPN. This was a so-called universal service obligation, meaning that KPN was obliged to place public phone boxes that were accessible from the street and ensure their continuous operation. The number of required telephone boxes was also set in advance, according to the number of inhabitants or the size of the city or town. This universal service obligation applied until 2008. In a letter to Parliament that year, the state secretary of Traffic and Water Management noted that he no longer saw the added value of telephone boxes, arguing that the mobile phone was now so popular that "public phone facilities on public land" had become redundant.

The liberalization of the public telecommunications market on 1 July 1997 made it possible for alternative fixed telephony providers, such as cable companies (phone services via coax cable) and internet companies (Voice over IP, or VoIP), to enter the market. In particular, the cable companies capitalized on the new situation. Public and semi-public networks owned by municipalities, housing associations, or special purpose foundations (which in the pre-liberalization era still required a Wtv licence) were taken over by private cable companies. These cable operators modernized the obsolete networks at breakneck speed, deploying fibreoptic cable to develop a fully-fledged infrastructure capable of accommodating two-way communication (telephony and internet access via the cable). The cable companies were the first to introduce broadband internet in the Netherlands. Their successful roll-out of digital telephony (VoIP) forced KPN to come up with a comparable VoIP service ("InternetPlusBellen"). The fixed line services of KPN were fully phased out on 1 September 2019, so that all voice telephony is now VoIP-based.

\subsection{Mobile Telephony}

Under the protection of a monopoly, the state-owned Staatsbedrijf der PTT launched the first mobile telephony services in the Netherlands. It all started with the ATF-1 car telephone network, which operated from 1980 to 1995 . ATF-1 had a maximum capacity of 2500 users, so there came a point where it could no longer cope with the demand. In 1985 ATF-2 was rolled out, followed in 1989 by ATF-3, the third-generation car telephone network with a capacity of 30,000 subscribers. Both networks remained operational until 1999. Meanwhile, GSM (Global System for Mobile Communication) had been introduced in 1994, originally only for business users. With the advent of GSM, competition was introduced into the market for mobile telephony for the first time. Towards the end of the 1990s, mobile telephony also started to be offered to consumers at affordable rates. Nationwide coverage was achieved in the Netherlands and the number of providers grew steadily. Today, we have reached the point where more than $80 \%$ of Dutch residents own a smartphone. The take-up rate among the elderly is lower, though the number of over-65s with a smartphone is rising fast (54\% in 2016) (Marketingfacts 2020). As for the younger generations, the smartphone has simply become a necessity of life, with over $95 \%$ owning such a device (Telecompaper 2017). However, contrary to what the experts had expected, fixed telephony has not been entirely wiped out by the much more convenient mobile phone. This is due to the popularity of the all-in-one packages in the Netherlands. These subscriptions, which are also known as "Triple Play", combine fixed telephony, internet and TV. The providers have made the all-in-one package cheaper than the individual services. In fact, the interactive TV and internet services are now the main cost drivers, with telephony almost thrown in for free. Due to this marketing strategy, the number of subscriptions that include fixed telephony remains as high as ever in the Netherlands. But this is mainly on paper. It is widely known that fixed telephony is now used much less than the mobile service. The extensive penetration of the smartphone testifies to this. However, due to the sensitivity of the information, no concrete data are known about the actual number of smartphone users versus fixed telephony users. 


\subsection{Identification of Actors, Objectives and Tactics}

The actors involved, their objectives and tactics from the case are indicated below in Tables 10 and 11.

Table 10. Private actors.

\begin{tabular}{cll}
\hline Private Actors & \multicolumn{1}{c}{ Objective(s) } & \multicolumn{1}{c}{ Tactics } \\
\hline Telephony operators & generate profit from telephony & apply for a concession \\
\hline Telephony customers & $\begin{array}{l}\text { secure a good-quality and } \\
\text { affordable connection }\end{array}$ & shop around for best deal \\
NV KPN & $\begin{array}{l}\text { generate profit, also from } \\
\text { telephony }\end{array}$ & $\begin{array}{l}\text { secure an exclusive concession } \\
\text { based on Wtv-VoIP } \\
\text { "Triple play" }\end{array}$ \\
\hline Private cable companies & $\begin{array}{l}\text { generate profit, also from } \\
\text { telephony }\end{array}$ & $\begin{array}{l}\text { VoIP } \\
\text { "Triple play" }\end{array}$ \\
\hline
\end{tabular}

Table 11. Public actors.

\begin{tabular}{|c|c|c|}
\hline Public Actors & Objective(s) & Tactics \\
\hline Municipalities & $\begin{array}{l}\text { secure good-quality, affordable } \\
\text { connection to service for residents }\end{array}$ & $\begin{array}{l}\text { terminate the concessions } \\
\text { awarded to operators } \\
\text { start their own telephony services }\end{array}$ \\
\hline \multirow{2}{*}{$\begin{array}{l}\text { Minister of Water Management, } \\
\text { Trade and Industry (Department } \\
\text { of Postal and Telegraphy Services) }\end{array}$} & \multirow{2}{*}{$\begin{array}{l}\text { terminate fragmentation of } \\
\text { telephony network } \\
\text { connection for everyone } \\
\text { good-quality affordable telephony }\end{array}$} & $\begin{array}{l}\text { public acquisition of long-distance } \\
\text { connections from the NBTM in } \\
1897\end{array}$ \\
\hline & & $\begin{array}{l}\text { public acquisition of the local } \\
\text { connections of the NBTM in } 1913\end{array}$ \\
\hline Public cable companies & $\begin{array}{l}\text { offer cable TV to subscribers on } \\
\text { equal terms and at an affordable } \\
\text { price }\end{array}$ & $\begin{array}{l}\text { statutory monopoly on communal } \\
\text { aerial installations } \\
\text { licence under the Wtv }\end{array}$ \\
\hline $\begin{array}{c}\text { Minister of Traffic and Water } \\
\text { Management }\end{array}$ & $\begin{array}{l}\text { offer voice telephony to everyone } \\
\text { on equal terms and at an } \\
\text { affordable price }\end{array}$ & $\begin{array}{l}\text { statutory monopoly on home } \\
\text { telephone installations } \\
\text { impose public service obligations } \\
\text { on KPN under the Wtv }\end{array}$ \\
\hline $\begin{array}{c}\text { Minister of Traffic and Water } \\
\text { Management }\end{array}$ & $\begin{array}{l}\text { create a competitive market for } \\
\text { mobile telephony }\end{array}$ & $\begin{array}{l}\text { abolish exclusive concession of NV } \\
\text { KPN for mobile telephony in } 1994 \\
\text { auction of airwave frequencies } \\
\text { under Tw }\end{array}$ \\
\hline $\begin{array}{c}\text { Minister of Traffic and Water } \\
\text { Management }\end{array}$ & $\begin{array}{l}\text { create a competitive } \\
\text { telecommunications market }\end{array}$ & $\begin{array}{l}\text { remove obstacles to competitive } \\
\text { telecom market from } 1 \text { July } 1997 \\
\text { OPTA as regulator }\end{array}$ \\
\hline
\end{tabular}

Table 12 shows the four relevant relationships from the case, as well as the formal legal instruments governing these relationships. The last column indicates the nature of the incentive.

The NBTM was forced to sell its long-distance network in 1897 to the ATP (Department of Postal and Telegraphy Services), followed by its local networks in 1913. This led to a completely closed market for fixed telephony. In the ensuing period, the state-owned Staatsbedrijf der PTT and its successor KPN NV (from 1945 to 1997) long held a monopoly on fixed telephony services based on an exclusive concession. The legal framework for this exclusive concession was provided in the first instance by the Telegraph and Telephone Act of 1904 and, from 1988, by the Telecommunication Services Act (Wtv). This led to a static period in which the freedom to innovate was severely inhibited. Initially, the market for mobile telephony was also hermetically closed as a result of the monopoly of the former state-owned company KPN NV. But the situation changed dramatically after 1994 when the auctioning of airwave frequencies opened the door to new entrants. This rapidly gave rise to a brand-new market 
with mobile telephony providers offering customers call minutes and phones in countless combinations. New companies were given more freedom of action, which is why the nature of the incentive can be classified as positive.

Table 12. Relevant legal relationships.

\begin{tabular}{ccc}
\hline Relationship & Legal Instrument & Nature of Incentive \\
\hline $\begin{array}{c}\text { NBTM versus Ministry of Water } \\
\text { Management, Trade and Industry }\end{array}$ & $\begin{array}{c}\text { termination of concession followed by } \\
\text { public/compulsory acquisition }\end{array}$ & negative \\
Staatsbedrijf der PTT/NV KPN & $\begin{array}{c}\text { exclusive concession under the } \\
\text { Telegraph and Telephony Act of } \\
\text { 1904/Wtv }\end{array}$ & negative \\
\hline $\begin{array}{c}\text { Staatsbedrijf der PTT/NV KPN versus } \\
\text { Minister of Traffic and Water } \\
\text { Management }\end{array}$ & $\begin{array}{c}\text { exclusive concession for mobile } \\
\text { telephony under the Telegraph and } \\
\text { Telephone Act of 1904/Wtv }\end{array}$ & negative \\
$\begin{array}{c}\text { Mobile telephony providers versus } \\
\text { Minister of Traffic and Water } \\
\text { Management }\end{array}$ & $\begin{array}{c}\text { licence for mobile telecommunication } \\
\text { frequencies }\end{array}$ & positive \\
\hline $\begin{array}{c}\text { Public and semi-public cable companies } \\
\text { versus Minister of Traffic and Water } \\
\text { Management }\end{array}$ & licence under Wtv & neutral \\
\hline
\end{tabular}

Initially, central or smaller communal aerial installations were held in public or semi-public hands (municipalities, foundations, or housing associations, etc.). The aerial installations required a licence under the Wtv. This licence could be obtained if certain conditions were met. For this reason, the nature of the incentive is classified as neutral. The aerial installations were originally intended for relaying TV and radio programs. Telephony via the cable has only been possible since 1995 . In the first instance, the cable telephone services were not stable and of poor quality. This only changed when the liberalization of the telecom market gave private cable companies access to the market. These cable companies were willing to invest in the construction of a fibre optic network. The resulting improvement in quality enabled cable telephone services to develop into a viable alternative for the traditional telephony services as provided by the telephone companies (or what were originally telephone companies).

\section{Conclusions}

In this contribution, we have coined the conception that government interventions can affect processes of technological transition through the enactment of legal and other policy instruments. We have concentrated primarily on legal interventions, and examined which ones were applied, how they affected the relation between public and private players, and whether they affected the degrees of freedom that innovators had in further developing their technological applications in positive or negative directions. We did this for four historical cases in the world of utility industries in the Netherlands in the nineteenth and twentieth centuries. For each of them, we described the technological transition, how the legal regime regulating the interaction among involved players changed over time, which players were involved, and how and which legal relations existed between these players that were affected by the changes in the legal regimes. Across the board, we can conclude that while the private innovators were mainly driven for love of financial gain and occasionally curiosity derived from a new technology, what motivated most national public authorities was the preservation of the market potential of the old technology that they had a share in and the financial and other benefits they derived from them, the integration of various previously fragmented utility networks, and public security (or at least what they perceived as such). Local governments shared some of these characteristics, but were also interested in the revenues they generated from old and 
new technologies, or were charged for them. Many, but not all, of the stimuli proved to have a negative impact on the prospects that innovators had of continuing and further developing these new technologies. The legal instruments with a negative effect on the position of private innovators were the obligation to apply for concessions, licenses or permits for operating services based on the new technology, restrictions imposed on these operations mentioned in those concessions, permits and licenses, legislation subjecting such operations and services to restrictions, taxes and exclusive rights granted to incumbent parties which wronged the position of newcomers. Other instruments of an at least partly legal nature were imposing a ban on services provided through the new technology, delaying the decision-making process regarding its acceptance or the granting of concessions, permits or licenses, the establishment of public monopolies for the old technology, and/or the acquisition of the new technology by the owner of the old technology. These negative incentives represented the overwhelming majority, and there was comparatively little that private decision-takers could do to overcome these legal and administrative hurdles. In a smaller number of circumstances in the four cases, the incentives were positive. This then happened through reserving facilities or capacities for services offered through the new technology, granting subsidies to newcomers but not to incumbents, imposing taxes on incumbents and making knowledge and expertise available to innovators to facilitate the development of new technologies. If the technological innovations under study eventually made it through, it was in spite of rather than due to government stimuli.

It is crucial to emphasize at this point that these are just four cases that occurred in just one nation in various periods. It is equally important to stress that the utilities are very specific industries with a mixture of public and private interests involved, and are likely to be unrepresentative of the broader gamut of innovating industries. Finally, we should not forget that these four technological innovations eventually did succeed, which may lead to a bias in our case selection when it comes to the impact of government regulation on technological innovation. Choosing failed cases of transition might well have made the impression even bleaker. All these limitations in our study make it risky to draw firm conclusions about the influence that governments and their legal actions have had on technological innovation around the world. Far more research is required to come to a deeper understanding of both the mechanisms driving the interaction between the public and private sectors in innovation and the role that legal instruments play this process. That said, it is hard to escape the conclusion that the common argument and rhetoric that governments normally aim to propel industrial progress by opening a variety of options for innovating private players rings hollow. Many more of the incentives we found across the four cases were negative than positive, while some had only negative incentives and none had more positive than negative ones. The lack of quantification does not allow for establishing any balance between the two. When it comes to drawing lessons from the above experience, one cannot help noticing that, especially when national or municipal players had financial stakes in services delivered through the established technologies, self-interest prevailed over lofty intentions to promote innovation. These institutional circumstances made developing balanced trade-offs between the opportunities and threats of new technologies an improbable task straight from the beginning. A reassessment of legal and financial government ownership in such industries deserves serious consideration. In addition to or in combination with that, the untrammelled application of concessions, permits, and licenses by public authorities is of questionable legitimacy. Should decisions not be reached within a reasonable limited timespan? Should these decisions not be made by impartial players, and/or should the grounds on which these concessions, permits and licenses not be clearly delineated and the range of restriction imposed on operations be more narrowly circumscribed? When the evolution of new technologies was thoroughly scrutinized, delayed or even banned for reasons of public safety and security, one may also argue that authorities were too conservative, but then it was at least not for self-serving motives.

The above findings are in line with Ten Heuvelhof et al. $(2001,2003,2009)$ who conducted their international studies into strategic actor behaviour in network-bound industries by governments, incumbents and newcomers to the market with ample examples from the 1990s and 2000s. What we 
believe we have added to the legal scholarship is a theoretical and methodological approach allowing for a systematic utilization of qualitative game theory where, firstly, (public and private) actors are mapped and connected with their ideal and material objectives and the tactics that they deployed to achieve them. Secondly, where the (legally) relevant actors are related to each other in their application of legal instruments and the stimuli which legally dominant decision-making public actors inflict on decision-taking private actors. We have not been able to apply this approach to cases in industries beyond the utilities and outside of the Netherlands, but are hopeful that this will lead to a more thorough understanding of the broader relevance of our results.

It is tempting to conclude or hope that the trend in more recent times is for governments to be more open to innovation and technological development and less embroiled in the wish to protect old public facilities that they have a stake in. Our fourth and most recent case did show a less negative record than the other three. Nonetheless, whether government has indeed become leaner, cleaner, and friendlier to novelty can not be unambiguously concluded. A far greater number of cases across a far larger selection of countries and greater variety of industries needs to be studied to substantiate such claims. What does seem to transpire is that the essential idea that public authorities are normally out to further technological development and undertake action conducive to the improvement of legal positions held by private players engaged in such innovation has not been echoed in their historic legal actions. As often said, actions speak louder than words.

Author Contributions: The theory and methodology were developed by M.d.J. and H.S.; the data were collected by H.S.; the analysis was by conducted by H.S. and M.d.J.; the conclusions were drawn by M.d.J.; the text was drafted by H.S. and M.d.J. All authors have read and agreed to the published version of the manuscript.

Funding: This research was funded by Erasmus School of Law and the Erasmus Initiative for the Dynamics of Inclusive Prosperity.

Conflicts of Interest: The authors declare no conflict of interest.

\section{Appendix A Legislative Materials}

- Bekendmaking van de Minister van Oorlog van 12 september 1917, Tweede Bijvoegsel tot de Nederlandse Staatscourant van 12 september 1917, 213. Intrekking van de bekendmakingen van 5 en 8 augustus 1914, houdende algemeen verbod van het gebruik binnen het Rijk van installaties voor draadloze telegrafie.

- $\quad$ Besluit opgedragen diensten, Staatsblad 1988, 551.

- Besluit van 15 december 1994, houdende wijziging van het Besluit opgedragen telecommunicatiediensten, Staatsblad 1995, 94.

- Commission Directive 90/388/EEC of 28 June 1990 on competition in the markets for telecommunications services. Official Journal of the European Union (OJ 1990, L192/10).

- Gemeentewet 1851, Wet regelende de samenstelling, inrichting en bevoegdheid van de gemeentebesturen van 29 juni 1851, Stb. 1851, no. 85.

- Hinderwet 1875, De wet tot regeling van het toezicht bij het oprichten van inrichtingen, welke gevaar, schade of hinder kunnen veroorzaken van 2 juni 1875, Stb. 1875, no. 95.

- Kamerstukken II, 1913-1914, 335, nr. 3 (memorie van toelichting ontwerp van wet tot aanvulling en wijziging van de wet van 11 januari 1904).

- Kamerstukken II 2007/08, 21 693, nr. 64 (brief van de staatssecretaris van EZ van 4 juli 2008).

- Koninklijk Besluit of 13 maart 1852, no. 16, tot machtiging van den Minister van Binnenlandschen Zaken, om te voorzien in de uitgaven voor den Rijkstelegraaf.

- Koninklijk Besluit van 6 maart 1905 tot vaststelling van een algemene maatregel van bestuur als bedoeld in artikel 12 van de Telegraaf- en Telefoonwet 1904 (Staatsblad n ${ }^{\circ}$. 7). Stb. 1905, 90.

- $\quad$ Nota Frequentiebeleid, Kamerstukken II 1994/95, 24 095, nrs.1 en 2. 
- Het ontwerp van wet tot aanvulling en wijziging van de wet van 11 januari 1904 (Staatsblad n. 7), betreffende aanleg, exploitatie en gebruik van telegrafen en telefonen, aangevuld en gewijzigd bij wet van 2 januari 1905 (Staatsblad $n^{\circ}$. 2).

- Telegrafenbesluit 1847; Koninklijk Besluit of 8 december 1847, no. 79, houdende bepalingen betreffende de invoering van electromagnetische telegrafen. Staatsblad 1847, 72.

- Telegraafwet 1904, Wet of 11 januari 1904, betreffende aanleg, exploitatie en gebruik van telegrafen en telefoon. Stb. 1904, 7.

- Telegraafwet van 21 maart 1919, houdende aanvulling en wijziging van de wet van 11 januari 1904 ((Staatsblad $\left.\mathrm{n}^{\circ} .7\right)$, betreffende aanleg, exploitatie en gebruik van telegrafen en telefonen, aangevuld en gewijzigd bij de wet van 2 januari 1905 (Staatsblad n. 2). Stb. 1919, 130.

- Trafiekenbesluit 1824, Koninklijk Besluit van 31 januari 1824, rakende de vergunningen ter oprichting van sommige fabrieken en trafieken, Stb. 1824, no. 19.

\section{References}

Butenko, Anna, and Pierre Larouche. 2015. Regulation for innovativeness or regulation of innovation? Law, Innovation and Technology 7: 52-82. [CrossRef]

Collette, A. E. R. 1904. Wet van den 11 Januari 1904 (Stbl. No. 7) Betreffende Aanleg, Exploitatie en Gebruik van Telegrafen en Telefonen. Met Algemeene Toelichting en Aanteekeningen. Bespreking van en Commentaar op de Telegraafwet 1904. The Hague: Staatsdrukkerij en Uitgeverij.

De Boer, Jacoba. 1946. Omroep en publiek in Nederland tot 1940. Deel I: De Plaats van de omroep in het openbare leven in Nederland tot 1940. Leyden: A.W. Sijthoff's Uitgeversmaatschappij.

De Jong, Martin, and Helen Stout. 2003. Strategic behaviour and the law: how legal authorities deal with factual strategic behaviour of former monopolists. International Journal of Technology, Policy and Management 3: 38-55. [CrossRef]

De Jong, Martin, and Helen Stout. 2007. The impact of government intervention in technological transitions: Evidence from Dutch history. International Journal of Technology, Policy and Management 7: 89-104. [CrossRef]

der Techniek, Stichting Historie. 1993. Geschiedenis van de Techniek in Nederland. De Wording van een Moderne Samenleving 1800-1890. Deel III Textiel, Gas, licht en elektriciteit, Bouw. Zutphen: Walburg Pers.

Di Castri, Simone, and Ariadne Plaitakis. 2018. Going beyond Regulatory Sandboxes to Enable FinTech Innovation in Emerging Markets. Available online: http://dx.doi.org/10.2139/ssrn.3059309 (accessed on 12 February 2019).

Dixit, Avinash K., and Barry J. Nalebuff. 1993. Thinking Strategically: The Competitive Edge in Business, Politics and Everyday Life. New York: W.W. Norton \& Company.

Dixit, Avinash K., and Barry J. Nalebuff. 2010. The Art of Strategy: A Game Theorist's Guide to Success in Business and Life. New York: W.W. Norton \& Company.

Fenwick, Mark, Wulf A. Kaal, and Erik PM Vermeulen. 2017. Regulation Tomorrow: What Happens When Technology Is Faster than the Law? American University Business Law Review 6: 561-94. [CrossRef]

Fenwick, Mark, Erik PM Vermeulen, and Marcelo Corrales. 2018. Business and Regulatory Responses to Artificial Intelligence: Dynamic Regulation, Innovation Ecosystems and the Strategic Management of Disruptive Technology. In Perspectives in Law, Business and Innovation. Edited by Toshiyuki Kono. Switzerland: Springer Nature.

Kunneke, Rolf, Aad Correlje, and John Groenewegen. 2005. Institutional Reform, Regulation and Privatization: Process and Outcomes in Infrastructure Industries. Cheltenham: Edward Elgar Publishers.

Kunneke, Rolf, John Groenewegen, and Francois Auger. 2009. The governance of network industries: institutions, Technology and Policy in Reregulated Infrastructures. Cheltenham: Edward Elgar Publishers.

Lamers, L. G. H. 1887. De Utrechtse Gasfabriek uit Rechtskundig Oogpunt Beschouwd. Utrecht: J. van Boekhoven.

Leenes, Ronald, Erica Palmerini, Bert-Jaap Koops, Andrea Bertolini, Pericle Salvini, and Federica Lucivero. 2017. Regulatory Challenges of robotics. Some guidelines for addressing legal and ethical issues. Law, Innovation and Technology 9: 1-44. [CrossRef]

Mac Lean, Johannes. 1977. Geschiedenis der gasverlichting in Nederland. Zutphen: Walburg Pers.

Marketingfacts. 2020. Available online: https://www.marketingfacts.nl/berichten/het-mobiel-gebruik-innederland-de-cijfers (accessed on 10 April 2020). 
Philipsen, Stefan, Evert Stamhuis, and Martin de Jong. 2020. Legal enclaves as a test environment for innovative products: towards legally resilient experimentation policies. Regulation E Governance. under review.

Rollema, D. W. 1995. Vijftig jaar VERON. Honderd jaar Radio. Gedenkboek ter Gelegenheid van het Vijftigjarige Bestaan van de VERON. Meppel: Krips Repro.

Schaafsma, Henk. 1970. Geschiedenis van de Omroep. Karakteristiek van de Omroep. Amsterdam: Wetenschappelijke Uitgeverij. Scharpf, Fritz. 1997. Games Real Actor Play: Actor-Centered Institutionalism in Policy Research. London: Routledge. Stout, Helen, and Martin de Jong. 2005. Over spreektelegraaf en Beeldtelefoon. De rol van de Overheid bij Technologische Transities in Infrastructuurgebonden Sectoren. Utrecht: Lemma.

Telecompaper. 2017. Available online: https://www.telecompaper.com/achtergrond/gebrui (accessed on 10 April 2020).

Ten Brink, Eduardus, Antonius Bernardus Josephus, and C. W. L. Schell. 1954. Geschiedenis van de Rijkstelegraaf 1852-1952, Staatsbedrijf der Posterijen, Telegrafie en Telefonie. The Hague: Staatsbedrijf der Posterijen, Telegrafie en Telefonie.

Ten Heuvelhof, Ernst, Kaspar Koolstra, and Helen Stout. 2001. Capaciteitsmanagement; Beslissen over Capaciteit van Infrastructuren. Utrecht: Lemma.

Ten Heuvelhof, Ernst, Martin de Jong, Martijn Kuit, and Helen Stout. 2003. Infrastratego. Strategisch Gedrag in Infrastructuurgebonden Sectoren. Utrecht: Lemma.

Ten Heuvelhof, Ernst, Martin de Jong, Mirjam Kars, and Helen Stout. 2009. Strategic Behavior in Network Industries: A Multi-Disciplinary Approach. Cheltenham: Edward Elgar Publishing.

Van den Noort, Jan. 1993. Licht op het GEB. Geschiedenis van het Gemeente-Energiebedrijf Rotterdam. Rotterdam: NV GEB.

Van Gestel, Rob, and Gijs Van Dijck. 2011. Better regulation through experimental legislation. European public law 17: 539-33.

Van Hulzen, A. 1976. Utrecht bij Gaslicht. The Hague: Kruseman's Uitgeversmaatschappij.

Zadoks, Simon. 1899. Geschiedenis der Amsterdamsche Concessies. Amsterdam: Van Holkema and Warendorf Uitgevers.

(C) 2020 by the authors. Licensee MDPI, Basel, Switzerland. This article is an open access article distributed under the terms and conditions of the Creative Commons Attribution (CC BY) license (http://creativecommons.org/licenses/by/4.0/). 